\title{
Recombinant human proinsulin expression in Pichiapastoris using PGK promoter
}

\author{
Enedina Nogueira de Assunçao ${ }^{1 *}$, Santos Maria Cristina dos ${ }^{2}$, Torres Fernando Araripe ${ }^{3}$, Astolfi-Filho Spartaco ${ }^{1}$ \\ From 5th Congress of the Brazilian Biotechnology Society (SBBIOTEC) \\ Florianópolis, Brazil. 10-14 November 2013
}

\section{Background}

There are indications, according to $\mathrm{WHO}$, that diabetes will reach 333 million people in 2025, and already is among one of the main death causes in the world. In 2030 in Latin America, diabetes mellitus will be the second cause of deaths [1]. The actions to increase the production of insulin are strategic to respond the high demands for what we have to face in the near future [2]. P. pastoris methylotrophic yeast is being very used in the last decades to express heterologous genes to biotech uses [3]. The main expression vectors to Pichia pastoris are based in the strong promoter from $A O X 1$ gene which codifies alcohol oxidize enzyme. However there is a search for new promoters than $A O X 1$ due to certain disadvantages as the use of methanol as inducer that is toxic and originates undesirable subproducts during its metabolism [4]. This work has the main objective in to express in high levels the human proinsulin in Pichia pastoris using PGK promoter.

\section{Methods}

The human proinsulin codifing sequence was chemically synthesized (Genone inc.) with P. pastoris optimized codons. The synthesized sequence was subcloned under PGK promoter control in expression vector together with the codifying region from Saccaromyces cerevisiae factor$\alpha$ signal peptide in order to have proinsulin expression/ secretion. After linearization the vector containing the expression cassete was introduced in P. pastoris GS115 by electroporation. To select clones, with multicopies of expression cassette, was realized a zeocin resistance test in plate [5]. Resistant clones to $100 \mu \mathrm{g} / \mathrm{mL}$ of zeocin were selected and submitted to crescent concentrations of the antibiotic: 500, 1000 and $2000 \mu \mathrm{g} / \mathrm{mL}$. The recombinant clones that produced/secreted more proinsulin was

'Divisão de Biotecnologia, Centro de Apoio Multidisciplinar Universidade Federal do Amazonas, UFAM Manaus, AM, Brazil

Full list of author information is available at the end of the article detected by imunodot procedure using antibody antiinsulin/proinsulin (Pierce-D3E7/5B6/6). Selected recombinant clones were cultivated in YPD medium for 24 hours in $30^{\circ} \mathrm{C}$ at $200 \mathrm{rpm}$ and the supernatants were clarified by centrifugation and analyzed by ELISA and Western-blotting.

\section{Results and conclusion}

From 200 zeocin $(100 \mu \mathrm{g} / \mathrm{mL})$ resistant $P$. pastoris clones 25 were able to grow in $2000 \mu \mathrm{g} / \mathrm{mL}$ which indicates that they have integrated several expression/ secretion cassetes in their genomes. From those one was notable for its higher human proinsulin expression/secretion in both experiments (imunodot and ELISA). The proinsulin overexpression of this selected clone was confirmed by PAGE and Western-blotting with anti-insulin/anti-proinsulin antibody. Additional experiments are in process in order to standardize the fermentative process for expression and secretion of human proinsulin as well as confirm recombinant protein amino acid sequence.

\section{Acknowledgements \\ This work was supported by CNPq, CAPES, FAPEAM and FAPDF.}

\section{Authors' details}

${ }^{1}$ Divisão de Biotecnologia, Centro de Apoio Multidisciplinar Universidade Federal do Amazonas, UFAM Manaus, AM, Brazil. ${ }^{2}$ Instituto de Ciências Biológicas, Universidade Federal do Amazonas, UFAM Manaus, AM, Brazil. ${ }^{3}$ Departamento de Biologia Celular, Universidade de Brasíli,a Brasília, DF, Brazil.

Published: 1 October 2014

\section{References}

1. WHO/NCD/NCS/99.2: Definition, diagnosis and classification of diabetes mellitus and its complications. World Health Organization 1999 [http://whqlibdoc.who.int/hq/1999/WHO_NCD_NCS_99.2.pdf], Accessed on 02.09.2012.

2. Brand-Miller Jennie: A Nova Revolução da Glicose. Rio de Janeiro: Campus/ Elsevier 2003. 
3. Fazenda S, Mcneil ML, Harvey B, L M: Heterologous protein production using the Pichia pastoris expression system. Yeast 2005, 22:249-270.

4. Almeida JRM, Moraes LMP, Torres FAG: Molecular characterization of the phosphoglycerate kinase (PGK1) from the methylotrophic yeast Pichia pastoris. Yeast 2005, 22:725-737.

5. Vassileva A, Chugh DA, Swaminathan S, Khanna N: Expression of hepatitis B surface antigen in the methylotrophic yeast Pichia pastoris using the GAP promoter. J Biotechnol 2001, 88:21-35, doi: 10.1016/S0168-1656(01) 00254.

doi:10.1186/1753-6561-8-S4-P88

Cite this article as: de Assunçao et al:: Recombinant human proinsulin expression in Pichiapastoris using PGK promoter. BMC Proceedings 2014 8(Suppl 4):P88.

\section{Submit your next manuscript to BioMed Central} and take full advantage of:

- Convenient online submission

- Thorough peer review

- No space constraints or color figure charges

- Immediate publication on acceptance

- Inclusion in PubMed, CAS, Scopus and Google Scholar

- Research which is freely available for redistribution

Submit your manuscript at www.biomedcentral.com/submit 